\title{
DELEGATION IN HARD TIMES: THE FINANCIAL MANAGEMENT OF ARM'S LENGTH BODIES IN THE UK
}

\author{
Katherine Tonkiss
}

\begin{abstract}
This paper explores the effectiveness of financial management tools in regulating the use of resources by arm's length bodies (ALBs) in a period of fiscal stress. The paper presents research undertaken into the implementation of a new financial management tool for ALBs in the UK since the 2008 financial crisis. Drawing on conflict ambiguity theory, the paper shows how the effectiveness of such tools is affected by deep-rooted tensions implicit within arm's length governance. This gives rise to microlevel conflict over the means of achieving fiscal regulation, underpinned by macro-level ambiguity over the logic of governance pursued by the government.
\end{abstract}

\section{Introduction}

The global financial crisis of 2008 and subsequent economic recession has meant that processes of financial management at the heart of governments around the world are under increasing scrutiny (Caperchione et al. 2014; Peters 2011; Papenfuß 2014). One consequence of this has been to focus attention on the financial management of arm's length bodies (ALBs; also called independent agencies, public bodies or quangos), organisations which spend public money to deliver key policy objectives but exist at 'arm's length' from ministerial control and therefore have far greater autonomy than government departments typically enjoy. In a climate of fiscal stress, stricter measures to oversee and control the finances of ALBs have been introduced (McCarthaigh 2012; Skelcher et al. 2013).

The purpose of this paper is to explore the effectiveness of financial management tools in regulating the use of resources by ALBs. The paper focuses on the implementation of a new financial controls framework in the UK, which was introduced in 2010. It employs the conflict-ambiguity model of policy implementation (Matland 1995) as a theoretical framework. This model, which has been largely overlooked by the arm's length governance literature, seeks to expose and analyse the different and often conflicting perceptions of different actors engaged in policy implementation. 
Through the analysis of extensive qualitative data, the paper shows that the introduction of the new financial control tool in the UK reflects a new model of financial management of ALBs, where the role of the core executive - and in particular the Cabinet Office - is strengthened. However, this new model is shown to have resulted in some perverse effects which limit its effectiveness. These effects can be explained by micro-level conflict over the means of achieving fiscal regulation within ALBs, underpinned by contrasting perceptions of independence and accountability of ALBs which themselves stem from macro-level ambiguity over the logic of governance pursued by the government, with both a centrifugal strategy of delegation to ALBs and a centripetal strategy of greater centralised control. At a broader level, therefore, the research suggests that the effectiveness of financial management tools in regulating the use of resources by ALBs is affected by deep-rooted tensions in delegated governance which come to the fore during periods of fiscal stress.

\section{The Delegated Finance Problem}

In many countries around the world, the new public management trend which developed since the 1970 s led to a large scale proliferation of ALBs, based on the idea that the autonomy of these bodies would make them more efficient and more flexible - and therefore would deliver greater capacity to be responsive to the needs of citizens (Hood 1991; McLaughlin et al. 2002; Pollitt and Talbot 2004). As a result, ALBs became key institutions in public service delivery.

This trend towards arm's length governance was, however, countered in the early $21^{\text {st }}$ century by a concern that the proliferation of ALBs was eroding accountability, bringing to the fore a desire on the part of governments to reassert political control (Kim 2003; Smullen 2010; Van Thiel 2011). The context of public sector austerity which resulted from the 2008 financial crisis and which has persisted into the second decade of the $21^{\text {st }}$ century has deepened this impetus for greater control. Public management has increasingly rejected the decentralising and deregulating logic of new public management and has instead turned to a range of centrally imposed 'cutback management' strategies to reconcile the delivery of quality public services with a desire to reduce public sector expenditure (Peters 2011; Papenfuß 2014; Leslie and Canwell 2010; Pandey 2010). For ALBs, this has meant reform and sometimes abolition of bodies 
in favour of more central control over policy delivery, and more control exerted over the bodies that remain.

Indeed, fiscal stress has led to what could be termed a 'delegated finance problem' in arm's length governance, where governments face the challenge of attempting to reap the benefits of delegation to ALBs while also curtailing their use of resources. Delegating to ALBs is widely recognised as a balancing act between autonomy and control aimed at maximising the efficiency and effectiveness of policy delivery (Barbieri et al. 2011; Verhoest et al. 2004; Verhoest 2005), but it is this very balance which is problematized at moments of financial crisis. The growth of governmental regulation of expenditure by ALBs is the key way in which governments have attempted to address the delegated finance problem, implementing financial management tools which more closely regulate the expenditure of ALBs while retaining the autonomy of ALBs to deliver policy objectives (Van Thiel et al. 2012).1

However, little is known about the effectiveness of these financial management tools in regulating the use of resources by ALBs. What factors affect this effectiveness? How is arm's length status reconciled with the desire for greater control? Research undertaken in the UK aimed to address these questions.

\section{Research Design}

The UK offers an ideal context in which to examine the effectiveness of financial management tools in regulating the use of resources by ALBs. Since the 1970s, there has been a large scale increase in ALBs as a result of the introduction of new public management reforms (Skelcher et al. 2000). Robust control mechanisms for ALBs have traditionally been absent, and together with 'ad hoc, unprincipled and asymmetrical' relationships between government departments and ALBs, led to a 'poor parenting' approach to the management of ALBs (Flinders 2008: 165).

It is in this context that the Coalition Government (2010-), in a climate of fiscal stress following the 2008 financial crisis, sought to strengthen relationships between

\footnotetext{
${ }^{1}$ It should be noted that autonomy and control are not binary opposites, and rather more autonomy may exist, for example, over the operational management of the ALB, while more control may be exerted over the policy direction, and so forth. The focus of this paper is on the managerial and financial aspects of autonomy and control, as per the typology of Verhoest et al. (2004; see also Verhoest et al., 2012).
} 
departments and ALBs and specifically to implement greater financial regulation of ALBs through the introduction of a new financial management tool. This blanket reform of the balance between autonomy and control experienced by ALBs has brought significant implications for the model of arm's length financial management in the UK.

Research undertaken in the UK in 2012-2013 sought to provide an understanding of the ways in which the new financial management tool has changed the financial regulation of ALBs, and the factors affecting how effective these changes have been in regulating the use of resources by ALBs. The research was qualitative in character, adding a new layer of insight to the existing rich quantitative research on arm's length autonomy and control (cf. Verhoest et al. 2012). A vast amount of data was collected for documentary analysis, including government publications as well as internal documentation relating to the new financial management tool (obtained via a contact within the Cabinet Office). Six semistructured, open-ended interviews were undertaken with senior civil servants in three Whitehall departments with responsibility for the implementation of the new financial control tool, with a further two interviews completed with Cabinet Office officials. The interviews focused on the process of implementation of the new tool, the effectiveness of the tool in regulating resource use, its effects on relationships between government and ALBs and its effects on ALB autonomy. These interviews were transcribed and analysed for common themes.

Additionally, a two-hour roundtable discussion with fifteen chairs of ALBs was held on the subject of the new financial management tool and its implications for arm's length status, as well as its effectiveness in regulating resource use. It was also then possible to contextualise this analysis within over one hundred further interviews conducted with politicians, civil servants and chairs of public bodies across Government which were undertaken for a wider project on public bodies reform of which the subject of this paper was just one part. The topic guide for these wider interviews included a question about the effect of the financial management tool on with relationships between departments and ALBs. All of the interviews lasted for one hour and participants were each interviewed once.

\section{Conflict-Ambiguity Theory}


Conflict-ambiguity theory presents a particularly useful way of exploring the implementation of the new financial management tool in the UK. Conflict-ambiguity theory is based on the assertion that policy implementation is shaped by the level of conflict over the policy to be implemented and the level of ambiguity present in the process of implementation (Matland 1995; for specific applications to financial/accounting policy see Arnaboldi and Lapsley 2009; Pipan and Czarniawska 2010; Schofield and Sausman 2004). In contrast to traditional models of policy implementation which are based on the presumption that implementation is a 'top-down' process (e.g. Pressman and Wildavsky 1973), the focus of the conflict-ambiguity approach is on the 'diverse micro-level contexts of implementation' (Wallace and Hoyle 2012, p.979) and the goals, interests and perceptions of actors within those contexts. It is particularly useful when considering complex implementation processes involving a multitude of different actors, such as in the case of arm's length governance where the regulation of resource use is implemented by actors both within government and in ALBs.

The approach defines conflict as occurring when more than one organisation perceives a policy to be relevant to its interests and when these organisations have clashing views. This conflict can be related to the goals that a policy is intended to achieve, or the plans for how the policy is to be implemented. Ambiguity is thought to arise when a policy comes to have more than one meaning to different actors in the process of implementation - and this can again be ambiguity of policy goals or ambiguity over the means of achieving those goals. The theory hypothesises that conflict is limited by increasing the ambiguity of a policy to be implemented, because if a policy is less clearly defined then it is more open to interpretation and less likely to be perceived to clash with interests (Baier et al. 1986; Hordern 2014; Matland 1995).

In the context of the present paper, the conflict-ambiguity lens complements an analysis of the top-down processes of implementation of the new tool with an analysis of relationships between the actors and organisations across government and ALBs, and the conflicts and ambiguities that arise between these actors in attempting to reconcile delegation with financial regulation in a fragmented organisational context.

\section{Towards a New Model of Financial Management}


To understand how the financial management of ALBs in the UK has changed in recent years, it is first necessary to set out the traditional model of financial management which was in effect prior to 2010. Under this traditional model, the financial management of ALBs was heavily delegated to the sponsor departments of government and to ALBs themselves. The Treasury took a strategic approach, setting departmental budgets on a three yearly basis (HM Treasury 2013a: 8). Departments were then at liberty to spend that budget according to their own priorities, and to make decisions about how much of that budget should be allocated to their ALBs - allocations which were set out in annual grant letters together with priority areas for spending. Permanent Secretaries were the Accounting Officers to Parliament for all money including that allocated to ALBs, and it was the responsibility of departments to 'ensure that [ALBs] are able to control the expenditure of their Public Bodies in order to stay within their limits' (Cabinet Office 2006b: 1). The delegation of authority to the ALB to spend this money was then set out in a Financial Memorandum for each ALB, which provided details on the ALB's funding arrangements, financial delegations, budgeting processes and banking (p.12).

This traditional model of financial management is set out in Figure 1. Parliament delegates authority for setting budgets and managing expenditure to the Treasury. The Treasury then sets departmental expenditure limits, and delegates responsibility for setting the expenditure limits of ALBs to departments. ALBs are then held to account for their expenditure through the production of an annual report and accounts, which is subject to approval by the Treasury and, ultimately, Parliament. The accounts of some ALBs - specifically those with advisory or tribunal roles which are typically smaller, with smaller budgets and no programme expenditure - are not presented separately to Parliament but rather as a part of the departmental accounts; however, the process of annual reporting is the same. Under this traditional model, ALBs are also held to account through internal and external financial auditing processes.

\section{FIGURE 1 AROUND HERE}

The relative independence of ALBs was emphasised under the traditional model. While it was noted that ' $[\mathrm{w}]$ here the $[\mathrm{ALB}]$ relies on government to finance all or part of its expenditure it will be necessary to decide what controls and safeguards are to be exercised by the sponsor department', it was also emphasised that '[i]n all cases the aim 
should be to delegate responsibility to the [ALB] to the maximum extent practicable where this offers improved value-for-money and can be done within an agreed policy and resources framework' (Cabinet Office 2006a, emphasis added). While the same document does give guidance on when an ALB should be more closely managed (i.e. where it holds a monopoly position or is financed by compulsory levy), it also notes that the general working assumption was that external market forces would drive efficiency and value for money, meaning that ALBs had the freedom, within the agreed processes and guidance, to manage their own expenditure.

However, since 2010 this model of arm's length financial management has been reformed, with significant implications for the financial freedom of ALBs. Austerity measures aimed at reducing the public sector budget deficit led to a tightening of departmental spending limits, as is reflected in the 2010 Comprehensive Spending Review. For example, the Department for Communities and Local Government faced an overall budget reduction of 33\% over four years, the Department for Energy and Climate Change 30\% and the Home Office 23\% (HM Treasury 2010: 48-61). These tightened departmental budgets had implications for the spending power of ALBs, because their budgets are funded from departmental budgets.

At the same time that these austerity measures were being implemented across the public sector, the government was also pursuing an agenda to reform the ALB landscape in the UK. In his rationale for this agenda, Minister for the Cabinet Office Francis Maude MP highlighted aims to 'increase accountability in public life', by bringing functions undertaken specifically by non-departmental public bodies (NDPBs - a specific subset of ALBs, distinguished from, for example, executive agencies and public corporations) back into government - and therefore under direct ministerial control, 'while making savings and driving out inefficiency and waste' (HC Deb 516) by removing the duplication of functions and improving the efficiency of bodies that remain. As a result, over 500 NDPBs were either abolished or significantly reformed (Dommett et al. 2013).

The goal of reducing spending across the public sector, together with the implementation of a significant programme of NDPB reform, has led to an emphasis on increasing the financial regulation of the ALBs that remain, in order to constrain the use of resources by those bodies while retaining their delegated status. The specific focus of initiatives to 
increase control is on administrative spending, while smaller budget allocations to ALBs as a result of smaller departmental budgets have driven efficiency in programme expenditure. In 2010, the government introduced a raft of controls on administrative spending, whereby spending over certain limits is subject to further approval from the Cabinet Office, who are delegated this authority by the Treasury.

The Treasury's core publication, Managing Public Money, which sets the standards and guidelines for all financial processes across Government, reflected this change when it was updated in 2013. It states that the Treasury 'may also work through the Cabinet Office to set certain standards applicable across government' (HM Treasury 2013b), something which was not included in the previous version (HM Treasury 2007). It should be noted that spending controls do not apply only to ALBs - they apply across spending departments as well - however, given that the remit of this article is to explore these changes with regards to the delegated finance problem, the focus here will be limited to ALBs.

The introduction of these financial controls represents a significant change in the traditional model of financial management of ALBs, towards a new model which accords a far greater role for the Cabinet Office. Parliament continues to delegate authority to the Treasury to lead on financial management, and the Treasury continues to allocate budgets to departments, thereby delegating the authority to set ALB budgets to those departments (and, as before, the Permanent Secretaries remain Accounting Officers to Parliament). However, the extent to which those ALBs then have the authority to spend their funds is 'subject to limits which may require approval' (HM Treasury 2013b: 9). This refers to powers that are delegated by the Treasury to the Cabinet Office (specifically, the Efficiency and Reform Group - ERG - of the Cabinet Office) to exert tightened regulation of spending in areas including IT, property, marketing, advertising, recruitment and consultancy (p.11). As Chief Secretary to the Treasury Danny Alexander MP, together with Francis Maude, explained in a letter to departments in 2011, these processes of tighter financial control are intended to provide 'government with the tools to ensure that operational spend is challenged closely: helping to ensure that we drive down spend on lower value areas to help protect our key priorities'. ${ }^{2}$

\footnotetext{
${ }^{2}$ Document obtained from the Cabinet Office.
} 
The powers delegated to the Cabinet Office are most clearly expressed in the Spending Controls Framework, a new financial management tool which sets out the limits within which departments can operate without Cabinet Office approval, and the point at which Cabinet Office or Treasury approval is required. Departments may permit ALBs to spend up to the level 1 limit without any further approval, or they may implement their own process under which ALBs are required to gain approval from their parent department before spending amounts of money below the level 1 limit. This is at the discretion of individual departments, and they may set an approvals process that is common to all of their ALBs, or they may apply more control over spending to bodies that, for example, are particularly high risk. ${ }^{3}$ Level 2 spend is that which is above the level 1 limit and requires Cabinet Office approval. Level 3 spend refers to 'major projects' funding, which involves very large amounts of money and requires Treasury approval in addition to that of the Cabinet Office. The full scope of the spending controls framework, together with the parameters of level 2 approvals, is set out in Table 1 .

\section{TABLE 1 AROUND HERE}

The spending controls framework has been implemented alongside other mechanisms designed to hold ALBs to account for good financial management. Together with the NDPB reform programme, the government also introduced a new process of Triennial Reviews, whereby NDPBs are reviewed every three years. These reviews focus on the extent to which specific functions of the body still need to be carried out at arm's length, and - if so - the quality of the governance of the body. One of the areas focused on in this governance element is effective financial management, under which it is expected that ' $\mathrm{t}$ ] he public body has taken appropriate steps to ensure that effective systems of financial management and internal control are in place' (Cabinet Office 2011a: 30-31). This includes annual reporting, internal and external audit functions, anti-fraud measures and rules governing the claiming of expenses. In many ways, this is similar to the accountability processes in place prior to 2010 that were detailed above, and explains how ALBs are held to account for non-administrative spending which is beyond the scope of the controls framework.

\footnotetext{
${ }^{3}$ Risk in relation to the governance of ALBs is typically thought of in terms of both financial risk (i.e. historical of poor financial management) and other issues such as the wider performance of the body or its political salience.
} 
Despite these similarities, the changes in financial management of ALBs detailed suggest that a new model has been developed, which involves tightened regulation of the finances of ALBs by central government and generates a far greater role for the Cabinet Office as a result of the delegation of authority from the Treasury. This model, showing the insertion of the Cabinet Office as a new actor in the system, is detailed in Figure 2.

\section{FIGURE 2 AROUND HERE}

How effective has this new model been in regulating the use of resources by ALBs, and what factors help to explain this effectiveness? This question is the subject of the next section.

\section{Regulating Resource Use through the New Model}

There is some evidence that the new model of financial management has been effective in regulating the use of resources by ALBs. In their first nine months of operation, the Cabinet Office claims that the new processes for regulating spending delivered $£ 133 \mathrm{~m}$ of savings on marketing and advertising, $£ 350 \mathrm{~m}$ savings on consultancy, a $75 \%$ reduction in recruitment activity and a $30 \%$ reduction in the recruitment of temporary staff. ${ }^{4} \mathrm{~A}$ recent study by the National Audit Office (2013) has also reported significant ongoing savings as a result of the implementation of the spending controls. As one civil servant described, 'if we're going to go to the Cabinet Office and ask for an exemption we need to be really clear as to why we're doing that. That perhaps makes them [ALBs] think about why they're doing it and perhaps could they do it in different ways' (participant 4).

However, attempting to regulate the resource use of ALBs has also given rise to some perverse effects. These are particularly apparent in instances of non-compliance with the controls framework. Non-compliance can be overt, i.e. spending money without seeking appropriate approval, and this was reported by a number of interviewees in the research (participants 1, 3 and 5). As one civil servant noted, 'in relation to ALBs, they're quite a tricky area. I think there's more effort on trying to circumvent the controls than there is on anything else' (participant 1), and another noted, 'you can encourage dysfunctional behaviour and then you can encourage people trying to sidestep controls, which is really not good' (participant 5).

\footnotetext{
${ }^{4}$ Data obtained from Cabinet Office. Figures refer to savings across both departments and ALBs.
} 
It can also take a less obvious form - that is, not incurring expenditure on projects that would otherwise have been undertaken on the grounds of not wanting to engage in the controls process. This latter form of non-compliance was also evident in the research. For example, one civil servant reported that 'bureaucracy that was created prevented people from spending money... they decided that [the process of gaining approval] simply wasn't worth the time and effort' (participant 3). Preparing business cases, writing up paperwork and processing cases through the system for level 2 and level 3 approval is time consuming for departments and ALBs. Departments estimate that $20 \%$ of this time involves departmental processes and 80\% involves Cabinet Office and Treasury approval mechanisms. While the National Audit Office (2013) notes that the Cabinet Office and Treasury are committed to deliver decisions on spending requests within a 28 day timeframe, the clock is stopped each time a query is raised. It is then not unusual for business cases to go through '30-40 iterations' as a result of such queries, and this has therefore meant that the 28 day timeframe has been stretched to as long as nine months (participant 1).

As such, it is not necessarily the case that the Cabinet Office, as the new actor in the system, is asserting direct control over spending. Rather, savings in spending may - at least in part - be due to non-compliance by not engaging in spending that would necessitate approval. This means that resources are being constrained, but that this is not occurring through the intended control mechanisms - essentially, government is not regulating what should be spent because ALBs are deciding not to spend. As one civil servant reflected, 'you're making it more difficult for people to spend money. So although you can deliver the desired outcome, which is reduced spend, you don't necessarily improve financial management' (participant 5). The immediate problem is addressed, but the deeper issues of control are not resolved. Conflict-ambiguity theory provides a useful lens for explaining why these perverse effects of non-compliance have arisen, and this explanation is illustrated in Figure 3.

\section{FIGURE 3 AROUND HERE}

There was very little conflict or ambiguity to be found in the research over the overall policy objective of reducing public sector expenditure. The main source of conflict was, rather, the means by which this policy objective was to be achieved with respect to ALBs 
- i.e. the new financial management tool - and it is this conflict which has driven those instances of non-compliance. The conflict is evident across two key themes. The first of these is independence. Conflict over the amount of independence that ALBs should be given was reported, as one chair noted at a roundtable session:

There is an important distinction between control - the line of control from ministers, and often that is confused with controls, which is the bureaucratic process. I don't think any of us would object in any way to control, but that has become so easily confused with lots and lots of detailed controls rather than the real function of control which should be about strategy (participant 8).

Evident here is a view that it is the role of government to oversee the strategy and policy direction of ALBs, but not the operational affairs of such bodies. Other chairs of ALBs similarly expressed the view that they feel they are being 'micromanaged' by their departments and the Cabinet Office. This was expressed by chairs as the erosion of accountability for decision-making' within ALBs (participant 7) as well as 'a threat to service delivery' on the grounds of the increasingly time consuming bureaucratic processes (participant 8), and as curtailing the ability of chairs to 'innovate with less resources' (participant 6) which was seen as a responsibility of chairs of ALBs who brought private sector experience to their roles. This conflict over independence was also reflected by civil servants, as one reflected:

There's always this thing about NDPBs because they seem to be independent. Sometimes they think that independence means the rules don't necessarily apply to them, because otherwise how can they be independent? I'm constantly having to tell them well you know it does apply to them because they're part of Government. That's I guess where sometimes things don't work as well as they could. It's the fact... how independent is independence? (participant 4)

The second conflict theme evident in the research is accountability. As was summarised in the traditional model, ALBs are typically held to account through the presentation of annual accounts to Parliament and through both internal and external audit. These mechanisms remain in place under the new model, however there are some perceptions 
that the introduction of the Cabinet Office's role in financial management has circumvented, or at least blurred, these lines of accountability in relation to administrative spending. This was summarised particularly well by one chair:

The spending controls have really affected us. It's a question of accountability. My argument is that the authority to spend certain amounts of money to fulfil what Parliament wants is a matter for myself and my colleagues. The way I expect to be held to account, rightly of course, is through the Secretary of State and Parliament through budget lines and all the rest of it, performance targets. (participant 9)

This sentiment was echoed by another chair: 'I have accountability to Parliament, but I'm increasingly finding more and more expectations through the National Audit Office and to the Cabinet Office controls and for me that affected me quite significantly - a significant line of accountability and not a very public one. There is some potential for conflict between them, it seems to me' (participant 10). The existence of 'turf battles' between public sector audit bodies and government is the subject of existing research (Bowerman et al. 2003), and the addition of the Cabinet Office in financial management practices may add to these complexities. The mention of 'public' in the quote also highlights the tension between the nature of parliamentary accountability which rests on the assumption that bodies which spend public money are held to account by representatives of the public, and the rather more hidden bureaucratic processes of gaining approval from the Cabinet Office.

These concerns were expressed by the Public Accounts Committee in relation to the extent to which the Cabinet Office spending approvals process compromises the Accounting Officers' responsibility to Parliament in securing value for money in public spending (National Audit Office 2013: 30). While there may be some grounds, therefore, to suggest that the new model has given rise to accountability problems, perceptions of accountability on the part of chairs reveal further tensions and conflicts in policy implementation. Chairs view their bodies as having a direct accountability relationship with Parliament and cast the Cabinet Office as diverting this accountability and curtailing their responsibility for their actions in the process. 
This latter point became particularly apparent in discussions of the implications of the new model for the accountability of the board of the ALB, including the accountability of the chair and chief executive. For example, one chair noted: 'the situation that we find ourselves in is that we have to have authorisations for things which I think I have authority to do' (participant 7), and another reflected on feeling responsible for actions and decisions:

You feel less responsibility for the decisions being made because, you know, someone else has made them. So my concept of accountability is that you feel responsible for the organisation that you are running, that's a really important managerial concept it seems to me. And it definitely undermines that a fair amount. (participant 10)

Similarly civil servants reflected on the extent to which perceived 'micro-management' had affected accountability and the tensions that this gave rise to. As one civil servant described:

Certainly they feel... that they are being micro-managed. Therefore their accountability has eroded. I would say if you put detailed controls in place you do take away the accountability of a body for its own budget because even they're not accountable for its decisions. It has to get somebody else to endorse them (participant 2).

Another tied this loss of accountability to trust in the ALB: 'it's recognising that there are things, if we were asked the question we might not spend the money in that way but we have to trust that the arm's length bodies will take responsibility' (participant 3).

In summary then, high degrees of conflict over independence and accountability affected the implementation of the new financial management tool for ALBs in the UK research and underpinned the problems of non-compliance experienced. The roots of this conflict can be observed in wider ambiguity over the logic of arm's length governance underpinning the policy objective to save public money. Attempts to increase central control over ALBs have coincided with the Civil Service Reform agenda which is designed specifically to 'hive off' functions out of central government responsibility in order to deliver efficiencies (HM Government 2012; Tonkiss and Noonan 2013). The coexistence of tightening regulation over ALBs at the same time as pursuing alternative 
models of service delivery with greater autonomy from government - such as the creation of mutuals to exercise public functions or the contracting out of those functions to the private sector - has created multiple models of financial regulation operating at arm's length.

As such, there is ambiguity over the model of governance that the government is pursuing to achieve efficiencies. It is continuing to deliver a wide range of services through ALBs and is further hiving off functions into even more delegated organisational forms, while at the same time implementing stronger financial regulation for ALBs with a strongly centralising logic. This macro-level ambiguity is feeding micro-level conflict over the means of achieving efficiency as a result of tensions over the applicability of different notions of independence and accountability. It is indicative of the inability of government to resolve the deeper tension between the perceived benefits to be gained from arm's length governance and the perceived accountability gains offered by more direct government control, and over how to deliver efficiency - to trust the agent or to closely regulate their use of resources.

\section{Conclusion}

This paper has explored the effectiveness of financial management tools in regulating the use of resources by ALBs, in a context where fiscal stress has led to the 'delegated finance problem' in arm's length governance; that is, governments face the challenge of attempting to reap the benefits of delegation to ALBs while also regulating their use of resources. The paper focused on the implementation of a new financial controls framework in the UK, drawing on conflict-ambiguity theory to help explain the unintended consequences of the introduction of this framework. Through its analysis, the paper demonstrated how problems of non-compliance were found in circumstances of micro-level conflict over the means of achieving a policy objective to reduce public sector spending. This conflict originated in tensions over independence and accountability, which themselves related to ambiguity over the model of arm's length governance pursued by the government.

As a result, the core finding of the paper is that the effectiveness of financial management tools in regulating the use of resources by ALBs is affected by deep-rooted tensions over independence and accountability in arm's length governance which come to the fore 
during periods of fiscal stress. This finding adds critical insight to the literature on arm's length governance by highlighting how autonomy and control dynamics are affected by financial crisis. It also has strong international relevance, as the very same countries which introduced ALBs as a result of the trend towards new public management now find themselves faced with financial crisis and the task of reconciling the logic of arm's length governance with greater financial oversight. It suggests that centripetal and centrifugal tensions within arm's length governance are not easily resolved and are likely to give rise to implementation challenges without careful strategic oversight - oversight which may be lacking during periods of financial crisis when there is impetus to act quickly (Peters 2011). This is also a critical insight for policy-makers and those tasked with implementation, as it highlights challenges in regaining administrative control over spending during periods of fiscal stress.

Finally, the paper raises critical insights for conflict-ambiguity theory. The research did not find instances of 'high conflict, high ambiguity' co-existing, and so this field of Figure 3 remains empty, in agreement with the findings of the wider conflict-ambiguity literature. However, the research demonstrates that conflict and ambiguity can co-exist at different levels - in this case, micro-level conflict over the means of implementation and macro-level ambiguity over the model of governance pursued. Further research could be undertaken to shed more light on how micro- and macro- levels of implementation and governance interact and the effects of this on policy implementation in other policy fields.

\section{References}

Arnaboldi, M. and Lapsley, I. (2009) On the implementation of accrual accounting: a study of conflict and ambiguity. European Accounting Review. 18 (4), 809-836.

Baier, V.E., March, J.G. and Saetren, H. (1986) Implementation and ambiguity. Scandinavian Journal of Management Studies. 2 (3-4), 197-212.

Barbieri, D. et al. (2013) 'Drivers of autonomy of public agencies in Italy'. Financial Accountability and Management. Vol. 29, no 1, pp.26-49.

Bowerman, M. et al., (2003) 'Struggling for supremacy: the case of UK public audit institutions'. Critical Perspectives on Accounting. Vol. 14, no 1-2, pp.1-22. 
Caperchione, E., Salvatori, F. and Benghi, E. (2014) Where there's a will, there's a way acting beyond cutbacks. Public Money and Management. 34 (2), 135-138.

Flinders, M. (2008) Delegated Governance and the British State: Walking Without Order (Oxford University Press, Oxford).

Gash, T. and Rutter, J. (2011) The quango conundrum. The Political Quarterly. 82 (1), 95101.

HM Government (2012) The Civil Service Reform Plan [online]

http://www.civilservice.gov.uk/wp-content/uploads/2012/06/Civil-Service-ReformPlan-acc-final.pdf.

Hood, C. (1991) A public management for all seasons? Public Administration. 69 (1), 3 19.

Hordern, J. (2014) An unfinished experiment: ambiguity and conflict in the implementation of higher skills policy. Research Papers in Education. DOI 10.1080/02671522.2013.879335.

Kim, P.S. (2003) 'Management innovation in quasi-governmental agencies in Korea'. International Review of Administrative Sciences. Vol. 69, no 4, pp.535-552. Leslie, K. and Canwell, A. (2010) Leadership at all levels: leading public sector organisations in an age of austerity. European Management Journal. 28 (4), 297-305. Matland, R.E. (1995) Synthesising the implementation literature: the ambiguity-conflict model of policy implementation. Journal of Public Administration Research and Theory. 5 (2), 145-174.

McCarthaigh, M. (2012) 'Shrinking the quango state: an international view'. Public Money and Management. Vol. 32, no 6, pp. 397-399.

McLoughlin, K., Osbourne, S.P. and Ferlie, E. (2002) New Public Management: Current Trends and Future Prospects. London: Routledge.

National Audit Office (2013) The Efficiency and Reform Group (The Stationery Office, London). 
Pandey, S.K. (2010) Cutback management and the paradox of publicness. Public Administration Review. 70 (4), 564-571.

Papenfuß, U. (2014) How (should) public authorities report on state-owned enterprises for sustainability and cutback management - a new quality model. Public Money and Management. 34 (2), 115-122.

Parker, L., and G. Gould (1999) 'Changing public sector accountability: critiquing new directions'. Accounting Forum. Vol. 23, no 2, pp.109-135.

Peters, B.G. (2011) Governance responses to the fiscal crisis - comparative perspectives. Public Money and Management. 31 (1), 75-80.

Pipan, T. and Czarniawska, B. (2010) How to construct an actor network: management accounting from idea to practice. Critical Perspectives on Accounting. 21 (3), 243-251.

Pollitt, C. and Talbot, C. (2004) Unbundled Government: A Critical Analysis of the Global Trend to Agencies, Quangos and Contractualisation. London: Routledge.

Pressman, J. and Wildavsky, A. (1973) Implementation: How Great Expectations in Washington Are Dashed in Oakland. Berkeley: University of California, Press.

Schofield, J. and Sausman, C. (2004) Symposium on implementing public policy: learning from theory and practice. Public Administration. 82 (2), 235-248.

Skelcher, C. et al. (2013) Public Bodies Reform by the UK Government 2010-2013: Initial Findings. http://www.shrinkingthestate.org.uk/

Skelcher, C. et al. (2000) Advance of the Quango State (LGIU, London).

Smullen, A. (2010) Transforming Agency Reform: Rhetoric and Culture in Comparative Perspective (Palgrave Macmillan, Basingstoke).

Tonkiss, K., and A. Noonan (2013) 'Debate: Arm's length bodies and alternative models of service delivery'. Public Money and Management. Vol. 33, no 6, pp.395-397.

Van Thiel, S. (2011) 'The Empty Nest Syndrome', in Van Thiel, S., et al. (eds.) New Steering Concepts in Public Management (Emerald, Bingley), pp.25-40. 
Verhoest, K., et al. (2004) 'The organisational study of autonomy: a conceptual review'. Public Administration and Development. Vol. 24, no 2, pp.101-118.

Verhoest, K. (2005) Effects of autonomy, performance contracting, and competition on the performance of a public agency: a case study. Policy Studies Journal. 33 (2), 235-258.

Verhoest, K., et al. (eds.) (2012) Government Agencies: Practices and Lessons from 30 Countries (Palgrave Macmillan, Basingstoke).

Wallace, M. and Hoyle, E. (2012) The dynamics of irony in organisational change: copy with a school merger. Public Administration. 90 (4), 974-999. 
Figure 1: Traditional Model of Financial Management of ALBs

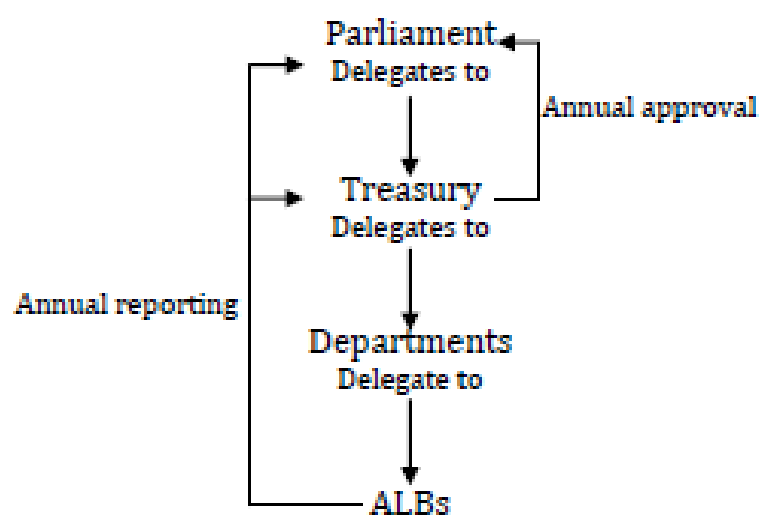


Table 1: Spending Controls Framework

Source: Cabinet Office (2013: 8-13).

\begin{tabular}{|c|c|c|}
\hline Control & Scope & Delegated limit \\
\hline $\begin{array}{l}\text { Advertising, } \\
\text { marketing and } \\
\text { communications }\end{array}$ & $\begin{array}{l}\text { Digital activity, publicity, events, } \\
\text { resources and materials, research, } \\
\text { strategy development, market } \\
\text { research, printing, publications, } \\
\text { events, public relations activity. }\end{array}$ & $\begin{array}{l}\text { Level } 2 \text { approval: } \\
\text { - spending above } £ 100 \mathrm{k} \text {. }\end{array}$ \\
\hline $\begin{array}{l}\text { Strategic supplier } \\
\text { management }\end{array}$ & $\begin{array}{l}\text { New expenditure, contract } \\
\text { extension, major contract } \\
\text { variation, disputes. }\end{array}$ & $\begin{array}{l}\text { Level } 2 \text { approval: } \\
\text { - spending above } £ 5 \mathrm{~m} \text { for new } \\
\text { expenditure, contract extension, or } \\
\text { contract variation } \\
\text { - any spending on disputes. }\end{array}$ \\
\hline $\begin{array}{l}\text { Commercial } \\
\text { models }\end{array}$ & $\begin{array}{l}\text { Disposals of businesses/assets, } \\
\text { outsourcing contracts, creation of } \\
\text { a new organisation. }\end{array}$ & $\begin{array}{l}\text { Level } 2 \text { approval: } \\
\text { - spending above } £ 5 \mathrm{~m} \text { on outsourcing } \\
\text { contracts } \\
\text { - any spending on disposals or new } \\
\text { creations. }\end{array}$ \\
\hline ICT & $\begin{array}{l}\text { ICT expenditure, common } \\
\text { infrastructure solutions. }\end{array}$ & $\begin{array}{l}\text { Level } 2 \text { approval: } \\
\text { - ICT expenditure above } £ 5 \mathrm{~m} \text { lifetime } \\
\text { costs } \\
\text { - ICT expenditure on administrative } \\
\text { expenditures above } £ 1 \mathrm{~m} \\
\text { - Common infrastructure solutions } \\
\text { above } £ 100 \mathrm{k} \text {. }\end{array}$ \\
\hline $\begin{array}{l}\text { Digital service } \\
\text { delivery }\end{array}$ & $\begin{array}{l}\text { Identity assurance, digital services } \\
\text { including the commissioning of all } \\
\text { government digital activity. }\end{array}$ & $\begin{array}{l}\text { Level } 2 \text { approval is needed for all } \\
\text { expenditure. }\end{array}$ \\
\hline Recruitment & $\begin{array}{l}\text { New permanent recruitment, new } \\
\text { temporary recruitment, } \\
\text { secondment from an external } \\
\text { organisation, extensions of } \\
\text { existing temporary recruitment. }\end{array}$ & $\begin{array}{l}\text { Cabinet Office is not directly involved in } \\
\text { approvals, however departments are } \\
\text { required to submit quarterly } \\
\text { recruitment forecasts to Cabinet Office. }\end{array}$ \\
\hline Consultancy & Central government consultancy. & $\begin{array}{l}\text { Level } 1 \text { approval: } \\
\text { - expenditure above } £ 20,000 \text {. } \\
\text { Level } 2 \text { approval: }\end{array}$ \\
\hline
\end{tabular}




\begin{tabular}{|l|l|l|}
\hline \multirow{2}{*}{} & & $\begin{array}{l}\text { - expenditure above } £ 20,000 \text { where } \\
\text { contracts are expected to exceed 9 } \\
\text { months, and for expenditure on } \\
\text { procurement related consultancy. }\end{array}$ \\
\hline Redundancy & Redundancy schemes. & $\begin{array}{l}\text { Level } 2 \text { approval is needed for all } \\
\text { schemes. }\end{array}$ \\
\hline learning & $\begin{array}{l}\text { Department-specific and generic } \\
\text { learning and development } \\
\text { services. }\end{array}$ & $\begin{array}{l}\text { Level } 2 \text { approval: } \\
\text { - generic learning and development } \\
\text { services. }\end{array}$ \\
& $\begin{array}{l}\text { New leases/licences and } \\
\text { - department-specific spend above } £ 10 \mathrm{k} .\end{array}$ \\
& $\begin{array}{l}\text { renewals, new acquisitions, new } \\
\text { build developments, new facilities }\end{array}$ & $\begin{array}{l}\text { Level } 2 \text { approval: } \\
\text { - rental expenditure above } £ 100 \mathrm{k} \text { during } \\
\text { the life of the lease commitment. } \\
\text { - new and extended facilities } \\
\text { management contracts. }\end{array}$ \\
\hline
\end{tabular}


Figure 2: New Model of Financial Management of ALBs

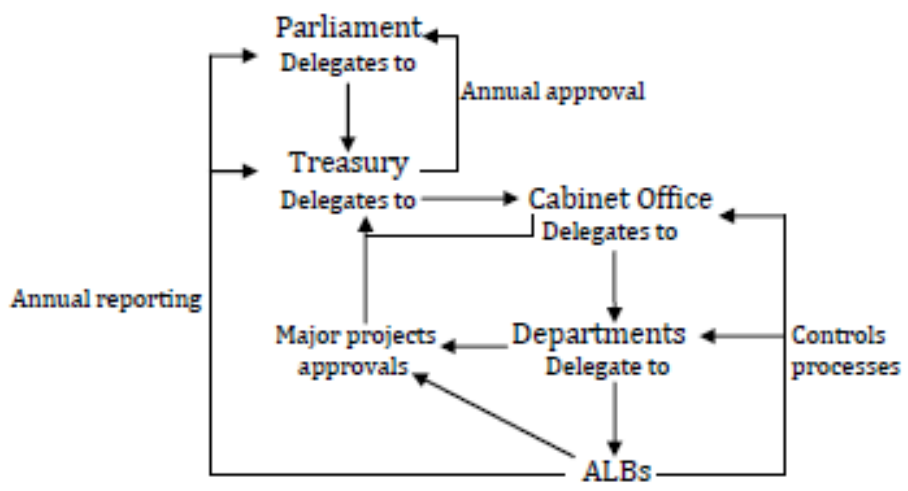


Figure 3. Conflict and ambiguity in the implementation of a new financial management tool for ALBs

\begin{tabular}{|c|c|}
\hline High Conflict, Low Ambiguity & High Conflict, High Ambiguity \\
Means of achieving policy objective & \\
\hline Low Conflict, Low Ambiguity & Low Conflict, High Ambiguity \\
\hline Policy objective to reduce public & Underpinning logic of governance \\
\hline expenditure & \\
\hline
\end{tabular}

